\title{
EDITORIAL BROADBAND FOR ALL
}

I n the early days of the New Deal's Tennessee Valley Authority, the slogan was "Electricity for All." Today, New Deal analogies guide the U.S. government's effort to bring affordable high-speed Internet to "underserved areas" nationwide. Broadband represents a new kind of electricity and phone system for the 21st century. President Obama describes it as a basic cost of doing business in the global economy, especially in the areas outside the big cities where it hasn't been economically feasible for ISPs to provide service.

Whatever one thinks of U.S. infrastructure priorities, broadband is now one of them, with a budget, modest as it is, and federal law behind it. National broadband investment is being funded under the American Recovery and Reinvestment Act of 2009. Broadband's $\$ 7.2$ billion slice of the Act's overall $\$ 787$ billion is intended to spur economic activity and create jobs in industries as diverse as electricity management, renewable energy, national security, education, health care, entertainment, and high-tech businesses of all kinds. Responsibility for spending the money is split between the National Telecommunications \& Information Administration and the U.S. Department of Agriculture Rural Utilities Service.

Which technologies will make it go? In his cover story "The Tech Behind Universal Broadband," Aaron Weiss says that broadband providers are sorting through wireless (the two most common forms are 802.11-based Wi-Fi and 3G-based cellular), 3G mobile (typically on licensed frequencies at $1900 \mathrm{Mhz}$ and $850 \mathrm{Mhz}$ ), next-generation wireless (like WiMax based on the 802.16 standard), the so-called "white space" spectrum (up to $50 \mathrm{Mbs}$ for short-range networking and perhaps $10 \mathrm{Mbs}$ for longer-range applications), wire (cable, DSL, or fiber), and broadband over power lines (modulating data signals at $10 \mathrm{Mhz}-30 \mathrm{Mhz}$ ). They'll also have to sign up millions of new users, some of whom are saying they don't miss or necessarily want it.

Reflecting on the historical roots of government investment in technology, Laurie Rowell follows with "We the People and the Right to Broadband," asking whether this emerging utility will indeed spur economic activity and jobs the way rural electrification did in the Tennessee Valley and beyond. Whatever arguments were leveled against the TVA, she says, it fulfilled its original contract and continues to have a significant economic influence in the area in which it operates.

Meanwhile, the law says the U.S. Federal Communications Commission has a year to develop a national broadband policy. The following year, after conducting a thorough analysis of the underserved areas, the Assistant Secretary of Commerce for Communications and Information is expected to make a broadband inventory map available to the public "in a form that is interactive and searchable" on a website of the National Telecommunications and Information Administration.

We'll follow how it plays out, even if you prefer to leave your city connections behind when you're in the country.

- Andrew Rosenbloom Executive Editor

DOI: $10.1145 / 1516035.1516036$ 